Dariusz Tułowiecki

Uniwersytet Kardynała Stefana

Wyszyńskiego w Warszawie
Etyka pracy socjalnej w filozofii spotkania i dialogu, red. M. Duda, I. Rybka, H. Kaszyński, Kraków 2017, s. 233-252

(Praca Socjalna w Teorii i Działaniu, 4).

DOI: http://dx.doi.org/10.15633/9788374386425.16

\title{
Dialog jako czynnik przełamywania ryzyka autowykluczenia społecznego pracoholików. Analiza opinii kobiet uciekających w pracę
}

Dialogue as a factor of overcoming the risk of social exclusion of workaholics. Analysis of the opinions of women withdrawing to work

Abstrakt: Pracoholizm jest jedną z form uzależnienia behawioralnego, które silnie powiązane jest $\mathrm{z}$ alienacją i ucieczką od życia. Artykuł jest raportem z badań młodych kobiet wykazujących znamiona ucieczki w pracę. Cechuje je przede wszystkim sukces ekonomiczny, poczucie autokreacji, wolności i niezależności. Część z badanych kobiet jest wysoce zadowolona $\mathrm{z}$ własnego stylu życia, inne doświadczają pustki i braków w relacjach. Kobiety z tej drugiej kategorii wyrażają opinię, że do dobrostanu wyraźnie brakuje im autentycznej bliskości, która możliwa jest jedynie w intymnym dialogu z rodziną: relacji damsko-męskiej, relacji w dziećmi, relacji z rodzica-
Abstract: Workaholism is a form of behavioral addiction strongly associated with social alienation and withdrawal from life. The article is a report of a research showing young women escaping into work. They are characterized, above all, by economic success, a sense of self-creation, freedom and by independence. Some of the women surveyed are highly satisfied with their lifestyle, while others are experiencing emptiness and relationship gaps. Women from the latter category are of the opinion that in order to be fully happy, they lack genuine intimacy only possible in affectionate dialogues within family, namely in female - male and parents - children relationships. 
mi, rodzinnej. Analiza zebranego materiału empirycznego pozwala na wniosek, że dialog i rozbudowane relacje rodzinne są w stanie wspomagać wychodzenie, a nawet przełamać autowykluczenie społeczne na skutek pracoholizmu.

Słowa kluczowe: pracoholizm, autowykluczenie, relacja, dialog.
Analysis of the collected empirical material leads to the conclusion that dialogue and extended family relationships are relevant factors in recovery from workaholism and even from social alienation caused by workaholism.

Keywords: workaholism, alienation, relationship, dialogue.

Aktualny stan badań nie pozwala na jednoznaczne określenia, czym jest pracoholizm i jaka jest jego natura. $Z$ tego też powodu badacze skupiają się nie tyle na wyjaśnieniu zjawiska, co jego opisie oraz wskazaniu konsekwencji indywidualnych i społecznych ${ }^{1}$. Takie podejście daje swoiste szanse oraz rodzi trudności: $\mathrm{z}$ jednej strony otwiera nowe przestrzenie badań, z drugiej - może prowadzić do problemów metodologicznych².

\section{Pracoholizm}

Uzależnienie od pracy, inaczej nazywane pracoholizmem, jest pojęciem bardzo powszechnie używanym nie tylko przez specjalistów w dyskursie naukowym, ale także w mowie potocznej. Najczęściej pracoholizm jest traktowany jako pewien dający się zaobserwować wyczerpujący (autodestruktywny i kompulsywny) sposób wykonywania pracy, kojarzony zwykle z długim czasem pracy lub pracą bez przerwy. W takiej sytuacji jedynym lekarstwem na pracoholizm byłaby zmiana zachowania, czyli zaprzestanie pracy lub zmniejszenie czasu pracy $^{3}$.

W potocznym znaczeniu - pracoholik to człowiek, który wiele czasu i wysiłku poświęca pracy, jest nią zaabsorbowany, a nawet sprawia wrażenie, że woli pracę niż inne zajęcia. Uzależniony od pracy bez aktywności czuje się źle, nie jest w stanie bez niej funkcjonować. W potocznym opisie pracoholizmu praca

D. Malinowska, Pracoholizm. Zjawisko wielowymiarowe, Kraków 2014, s. 15.

2 K. Wojdyło, Pracoholizm - istota konstruktu i trafność nomenklatury jako aktualne problemy w badaniach nad zjawiskiem. Komentarz do Staszczyk i Tokarz (2015), „Roczniki Psychologiczne" 2015, nr 4, s. 546.

3 E. Hornowska, W. J. Paluchowski, Praca - skrywana obsesja. Wyniki badań nad zjawiskiem pracoholizmu, Poznań 2007, s. 11. 
wskazywana jest jako regulator jakości życia, a jej nadmiernie podkreślana pozycja budzi niepokój $j^{4}$. W nazewnictwie zjawiska dostrzegalna jest też swoista niekonsekwencja. Pojawiają się różne kategorie opisu, w których używane są następujące terminy: postawa, zachowanie, zaburzenia psychiczne, uzależnienie, zaburzenie obsesyjno-kompulsywne, brak kontroli impulsów5

W międzynarodowej literaturze przedmiotu mianem pracoholizmu określa się ,zaburzenia obsesyjno-kompulsywne, przejawiające się przymuszaniem samego siebie do pracy, niemożnością regulowania własnych nawyków związanych z pracą i nadmiernym zaangażowaniem się w nią, aż do zaniedbywania innych czynności życiowych"6. W naukowej literaturze wymienia się dwie równie istotne przyczyny powodujące utratę kontroli nad czasem poświęconym pracy. Jedna $\mathrm{z}$ nich to pragnienie osiągnięcia celu, do którego ona prowadzi lub przyjemność doświadczana w jej trakcie. Wówczas praca staje się czynnością wysoce wynagradzającą. Druga przyczyna - to przymus pracy - rodzący niepokój, lęk, napięcie w sytuacji jej zastopowania. W obu przypadkach czynnikiem sterującym są emocje. W pierwszym z nich - to potrzeba utrzymania doświadczenia zadowolenia i przyjemności, w drugim - pragnienie uniknięcia niepożądanego napięcia i lęku. Badacze zjawiska różnicują ocenę obu motywacji. Pierwszą - nazywaną niekiedy entuzjazmem pracy - identyfikują jako odbieraną pozytywnie, drugą - to znaczy przyznanie się do tego, że osoba bez pracy czuje negatywne napięcie, że praca jest jej potrzebna, by wrócić do emocjonalnej równowagi - określają jako przymus pracy i uzależnienie od niej

Wiele badań konsekwentnie wskazuje powyższe rozróżnienie na pracoholizm i entuzjazm pracy. Są to odmienne zjawiska oparte na różnych mechanizmach motywacyjnych. Wiele międzynarodowych badań pozwala wnioskować, że pracoholików cechuje wysoka motywacja kontroli, natomiast entuzjastów pracy - motywacja autonomiczna ${ }^{9}$. Pracoholizm jest związany głównie z kontrolną samoregulacją (introjektywną), polegającą na presji zewnętrznych standardów poczucia wartości i społecznego uznania oraz orientacją na zapobieganie porażce. Natomiast entuzjazm pracy jest związany przede wszystkim

L. Golińska, Pracoholizm inaczej, Warszawa 2014, s. 11.

D. Malinowska, Pracoholizm. Zjawisko..., dz. cyt., s. 16.

$6 \quad$ E. Łuczak, Pracoholizm - droga do sukcesu czy zniewolenia, w: Nowe oblicza uzależnień, red. E. Łuczak, Olsztyn 2009, s. 151.

L. Golińska, Pracoholizm inaczej..., dz.cyt., s. 11; K. Wojdyło, Work craving - teoria uzależnienia od pracy, „Nauka” 2013, nr 3, s. 87.

$8 \quad$ K. Wojdyło, Work craving - teoria..., dz. cyt., s. 87.

9 I. van Beek, T. W. Taris, W. B. Schaufeli, V. Brenninkmeijer, Heavy work investment: its motivational make-up and outcomes, „Journal of Managerial Psychology” 29 (2014), nr 1, s. $47-49$. 
z samoregulacją wewnętrzną, opartą na własnych standardach i orientacją na dążenie do sukcesu ${ }^{10}$. W niniejszym opracowaniu przyjmuje się, że odmienne mechanizmy motywacyjne leżące u podstaw dwóch rodzajów pracy: zdrowego - entuzjazmu pracy i patologicznego - pracoholizmu, są związane z dwoma odmiennymi stanami emocjonalno-motywacyjnymi: entuzjazm pracy - to afektywno-motywacyjny stan umysłu odmienny od pożądania pracy (work craving) ${ }^{11}$.

Autorem samego terminu „pracoholizm” jest Wayne Oates, który w 1971 roku dokonał następującego opisu zjawiska: „Pracoholik to osoba, której potrzeba pracy jest tak wielka, że zaspokajanie jej wywołuje znaczne dolegliwości i wywiera wpływ na stan zdrowia, osobiste szczęście, relacje międzyosobowe i społeczne”. Pracoholik na ogół, poprzez całkowite oddanie się pracy, stara sie dużo pracować, a przez to podnosić swą samoocenę. Praca staje sie narzędziem próby pozbycia się niepokoju, pustki i polepszenia samooceny ${ }^{12}$. Twórca pojęcia użył go intencjonalnie i podobnie jak w terminie alkoholizm, w workaholizm - złożył dwa człony: work - praca i holizm, od greckiego holos - cały. Wierne tłumaczenie oznacza zatem „cały pracą”. Użycie takiego terminu było celowe i miało wskazywać na fakt, że praca stała się koniecznym elementem funkcjonowania człowieka, że jest od niej uzależniony. Definicja Oates’a akcentuje dwie najbardziej podstawowe cechy uzależnień: przymus i utratę kontroli. Przymus w przypadku pracoholizmu to rodzaj kompulsji, która sprawia, że pracoholik poświęca jej bardzo dużo czasu, przypisuje wyjątkową wartość oraz traci kontrolę nad swoim życiem właśnie na rzecz pracy. Potrzeba pracy nie podlega już żadnej kontroli ${ }^{13}$.

Wayne Oates zaliczył pracoholizm do uzależnień: workaddiction. Wyodrębnił w uzależnieniu: cierpienie z powodu głodu pracy, brak kontroli nad potrzebą wykonywania pracy, natrętne myśli z nią związane, występowanie zespołu abstynenckiego. I choć pracoholicy poświęcają wiele czasu na wykonywanie swoich obowiązków, to zdaniem Oates'a, nie ten czas przede wszystkim definiuje uzależnienie, ale wewnętrzne nastawienie do pracy, psychologiczne z nią związanie, miejsce, jakie ona zajmuje w zestawieniu $\mathrm{z}$ innymi ważnymi obszarami życia.

10 I. Ahmed, M. K. Khan, Predicting Work Motivation Through Job Satisfaction and Turnover Intentions: The Explanatory Role of Heavy Work Investment, „The Lahore Journal of Business" 4 (2015), no. 1, s. 75-89; por. K. Wojdyło, Work craving - teoria..., dz. cyt., s. 87.

11 Por. I. van Beek, Q. Hu, W. B. Schaufeli, T. W. Taris, B. Schreurs, For fun, love, or money: What drives workaholic, engaged, and burned-out employees at work?, „Applied Psychology” 1/2012, (61), s. 30-55; I. Ahmed, M. K. Khan, Predicting Work Motivation Through Job Satisfaction and Turnover Intentions: The Explanatory Role of Heavy Work Investment, „The Lahore Journal of Business" 4 (2015), No. 1, s. 75-89.

12 C. Guerreschi, Nowe uzależnienia, Kraków 2005, s. 122.

13 L. Golińska, Pracoholizm inaczej..., dz. cyt., s. 13-14. 
Pracoholizm to zaburzenie, które można definiować jako zaburzenie równowagi pomiędzy pracą a innymi wymiarami życia ${ }^{14}$. Pracoholik to osoba, „której potrzeba pracy stałą się tak nieumiarkowana, że powoduje widoczne zaburzenia i zakłócenia w jej fizycznym zdrowiu, osobistym szczęściu, w stosunkach interpersonalnych i w jej funkcjonowaniu społecznym"15.

Badacze zjawiska stwierdzają, że pracoholizm jest jedynym uzależnieniem, któremu nie towarzyszą zawstydzenie i próba zamaskowania. Jest to uzależnienie, które bywa wprost ostentacyjnie demonstrowane z intencją wywołania uznania i aprobaty ze strony niewtajemniczonych obserwatorów. Większość nierozpoznających znamion uzależnienia i ucieczki widzi jedynie pracowitość, zyski finansowe, prestiż $\mathrm{w}$ firmie, poziom ekonomiczny rodziny. W potocznym mniemaniu nadmierna praca bywa utożsamiana z odpowiedzialnością i troską o byt materialny rodziny. Wiąże się on także ze stereotypem pracowitości: solidnością, odpowiedzialnością, konsekwencją, wytrwałością ${ }^{16}$.

Pośród wielu badań nad zjawiskiem pracoholizmu poszczególni badacze różnią się w sposobie traktowania źródeł, przyczyn, psychicznych przejawów i konsekwencji pracoholizmu. Niemniej jednak pracoholizm można określić jako: a) niekontrolowane uzależnienie, b) forma ucieczki od osobistych problemów, c) wyraz ekstremalnego zapotrzebowania na kontrolowanie swojego życia, d) efekt wysoce kompulsywnej osobowości, e) powielanie modelowanych przez rodziców i utrwalonych zachowań, f) skutek niekorzystnej niesprawiedliwości i zły obraz siebie: nieadekwatna samoocena, niestabilne poczucie własnej wartości ${ }^{17}$.

O złożoności problemu może świadczyć różnorodność symptomów, wielość typów pracoholizmu, wielość punktów spojrzenia na uzależnienie od pracy. Jednym $z$ nich jest charakteryzowanie pracoholika z punktu widzenia jego cech, stylów funkcjonowania i nastawień do pracy. To spojrzenie reprezentuje Marilyn Machlowitz, wedle której pracoholików charakteryzują: duża energia, rywalizacja, intensywność własnych działań, niestabilność i chwiejność samooceny, przedkładanie pracowitości nad lenistwo, a aktywności nad odpoczynek, stałe zajęcie pracą. Uzależnieni zdecydowaną większość swego czasu są aktywni, mają rozmyte granice pomiędzy pracą a przyjemnością, co prowadzi do uznania pracy za przyjemność. „Praca pracoholika nieomal zawsze przewyższa przypisany mu zakres obowiązków oraz oczekiwania względem

\footnotetext{
14 E. Hornowska, W. J. Paluchowski, Praca - skrywana obsesja..., dz. cyt., s. 12.

15 W. Oates, Confessions of a workaholic: The facts about work addiction, New York 1971, s. 4.

16 L. Golińska, Pracoholizm inaczej..., dz. cyt., s. 14.

17 J. Wachowiak, Dysfunkcyjne zachowania pracowników, Warszawa 2011, s. 25.
} 
ludzi, z którymi lub dla których on pracuje: pracoholicy pożądają nieustannej stymulacji i posiadają obfitość energii”. Wedle badacza pracoholik, odnajdując radość w pracy, w niej poszukuje, i odnajduje, „fascynacji uwikłania” i gratyfikacji. Pracoholicy nie pracują dla pieniędzy, ale dla zysków niematerialnych - „psychicznych dochodów”, które są tożsame z odpowiedzialnością, sensownością, znaczeniem, wykorzystaniem sposobności i uznaniem. Satysfakcja z pracy jest ważniejsza niż relacje domowe ${ }^{18}$.

Inną drogą do analizy pracoholizmu jest poszukiwanie przyczyn ucieczki w pracę. Zdaniem Melvina L. Kohna kompulsja jest sposobem radzenia sobie ze stresem, a nie jego skutkiem ${ }^{19}$. Przy takim podejściu za symptomy uzależnienia uważane są następujące problemy emocjonalne: zaburzenia lękowe i depresyjne nasilające się przez cechy obsesyjno-kompulsywne ${ }^{20}$. „Można więc powiedzieć, że podłożem do podjęcia tego typu działań będzie „depresja o średnim natężeniu” ${ }^{21}$ „ „W pracoholizmie praca staje się skutecznym [...] sposobem radzenia sobie ze stresem: podjęcie pracy oznacza podwyższenie poziomu aktywacji, zwiększa energię, a równocześnie daje zdystansowanie do tego, co poza nią i pośrednio uspokaja"22.

Z kolei Klat, Killinger i Kleiner twierdzą, że praca jest formą zabezpieczenia przed lękiem związanym z porażką. Praca może dawać pozorne wrażenie kontroli tego, jak długo i w jaki sposób człowiek się nią zajmuje. „Pracoholizm jest formą ucieczki od trudów i problemów. Zanurzenie się w pracę jest ucieczką od prywatnego życia"23.

Innym podejściem jest spojrzenie na pracoholizm jako na uzależnienie, które ma dynamiczny charakter i nasilający się przebieg. Pracoholizm sytuuje się w kategorii uzależnień substancjalnych - czynnościowych. Ta grupa uzależnień związana jest $\mathrm{z}$ wykonywaniem pewnych czynności i dotyczy na przykład hazardu, jedzenia, korzystania z Internetu, wykonywania ćwiczeń fizycznych, zachowań seksualnych, wykonywania pracy zawodowej ${ }^{24}$.

Oates, wprowadzając pojęcie pracoholizmu do języka nauki, zaproponował także kategorie pracoholizmu. W procesie kategoryzacji wziął pod uwagę piętno „przymusu pracy”, „obsesyjne zaburzenia”, które oddziałują na życie rodzinne, rozwój osobisty i stosunki interpersonalne. Wyodrębnił kategorie:

\footnotetext{
18 L. Golińska, Pracoholizm inaczej..., dz. cyt., s. 14-15.

19 A. Judzińska, Niekonwencjonalna walka ze stresem - konteksty i kulturowe uwarunkowania, „Studia Edukacyjne” 2015, nr 35, s. 141.

$20 \quad$ L. Golińska, Pracoholizm inaczej..., dz. cyt., s. 15.

21 L. Golińska, Pracoholizm - uzależnienie czy pasja, Warszawa 2008, s. 13.

22 L. Golińska, Pracoholizm - istota, konsekwencje i uwarunkowania, „Folia Psychologica" 2010, nr 14, s. 100.

23 L. Golińska, Pracoholizm inaczej..., dz. cyt., s. 15.

24 D. Malinowska, Pracoholizm. Zjawisko..., dz. cyt., s. 16-17.
} 
a) pracoholizm „do szpiku kości” (dyed-in-the-wool) - to perfekcjoniści zaangażowani w swe aktywności, którzy stawiają sobie wysoko cele i drażni ich brak kompetencji; b) pracoholicy „nawróceni” (converted workaholisc) - osoby, które przestały być pracoholikami, dbają o swój wolny czas, nie podejmują podczas niego pracy ani innych dodatkowych obowiązków; c) pracoholizm sytuacyjny (sytuacional workaholisc) - pracoholicy pracujący po to, by mieć poczucie bezpieczeństwa, nie mają osobowości typowej dla pracoholika; d) pseudopracoholizm (pseudoworkaholisc) - osoby przypominające prawdziwych pracoholików, ale ich zaangażowanie w pracę wynika z innej motywacji: z chęci zdobycia władzy i pozycji zawodowej; e) pracoholicy eskapici (escapit workaholisc) - pracoholicy traktujący pracę jako ucieczkę przed różnymi sytuacjami, np. rodzinnymi ${ }^{25}$.

Badanie zjawiska ucieczki w pracę jest procesem otwartym i mającym szerokie perspektywy w różnych kulturach, w ramach teorii psychologicznych i społecznych oraz wielu dziedzinach nauki. Badaniom modeli uzależnienia od pracy towarzyszy naukowe poszukiwanie społecznych konsekwencji uzależnień oraz dróg pomocy i terapii ${ }^{26}$.

\section{Pracoholizm jako źródło wykluczenia społecznego}

Zjawisko wykluczenia społecznego jest także trudne do zdefiniowania. Historia pojęcia jest znacznie krótsza niż terminów „marginalizacja” czy „marginalność". Jego stosowanie uwalania dotychczasowe określenia (patologia, margines społeczny) od pejoratywnych konotacji ${ }^{27}$. Jest ono pojęciem przeciwstawnym do społecznego uczestnictwa w szerszych zbiorowościach. Oznacza ono

25 B. Dudek, Pracoholizm - szkodliwy skutek nadmiernego zaangażowania sie w prace, „Medycyna pracy” 59 (2008), nr 3, s. 250.

${ }_{26}$ Por. R. Snir, I. Harpaz, Beyond workaholism: Towards a general model of heavy work investment, „Human Resource Management Review” 22(2012), s. 232-243; W. B. Schaufeli, A. Shimazu, T. W. Taris, Being driven to work excessively hard: the evaluation of a two-factor measure of workaholism in the Netherlands and Japan, "Cross-Cultural Research" 43(2009), s. 320-348; W. B. Schaufeli, T. W. Taris, W. Van Rhenen, Workaholism, burnout, and engagement: three of a kind or three different kinds of employee well-being?, „Applied Psychology: An International Review”, 57 (2008), No. 4, s. 173-203; M. Giannini, A. Scabia, Workaholism: An Addiction or a Quality to be Appreciated?, „Journal of Addiction Research \& Therapy" 5 (2014), No. 3, w: https://www.omicsonline.org/open-access/workaholism-an-addiction-or-a-quality-to-be-appreciated-2155-6105-5-187.php?aid=30501 (19.04.2017).

27 D. Tułowiecki, Aktywność seniorów jako sposób na przełamanie wykluczenia społecznego w opisach prasy regionalnej, „Studia nad Rodziną” 33 (2013), nr 2, s. 381. 
izolację dobrowolną lub wymuszoną warunkami zewnętrznymi. Alienacja jednostek lub grup społecznych od zbiorowości, od instytucji współczesnego państwa, a także szeroko rozumianego życia społecznego, utrwala podział na „naszych” i „obcych”, dramatycznie spychają na margines „nieprzydatności” duże grupy ludzi ${ }^{28}$.

Wykluczenie społeczne jest złożonym zjawiskiem o wielu przyczynach. Przyjmuje się na ogół, że jest zarówno stanem, jak i procesem, ma charakter kumulatywny, przejawia się zerwaniem więzi społecznych i rodzinnych oraz wykazuje tendencje do reprodukcji ${ }^{29}$. Wśród teoretyków zajmujących się zjawiskiem i skalą wykluczenia istnieje żywa dyskusja wokół obszarów społecznego wykluczenia ${ }^{30}$. Antony Giddens na przykład twierdzi, że wykluczenie społeczne „odnosi się do sytuacji, w której jednostki zostają pozbawione pełnego uczestnictwa w społeczeństwie”, zaś sam termin różni się od pojęcia „podklasy” i „ubóstwa”. Wyróżnia on również - ważne dla niniejszej analizy - trzy kategorie wykluczenia: ekonomiczną, polityczną i społeczną. Wykluczenie ekonomiczne może dotyczyć zarówno produkcji, jak i konsumpcji. W produkcji - nastąpić może wyłączenie z rynku pracy i zatrudnienia, w konsumpcji - odejście od wzorów konsumpcyjnych: typu zakupów, stanu posiadania, przestrzeni konsumpcji (wykluczać może brak mieszkania, konta bankowego, Internetu, telefonu komórkowego). Wykluczenie polityczne polegać może na braku dostępu do informacji o zachodzących procesach politycznych, środków i możliwości niezbędnych do czynnego uczestnictwa w życiu politycznym. Wykluczenie społeczne - oznacza niski udział w życiu publicznym, niskie wskaźniki używalności obiektów publicznych, słabo rozwiniętą sieć relacji społecznych prowadzącą do izolacji i atomizacji ${ }^{31}$.

Obok powyższych trzech, Barbara Satur-Jaworska proponuje także czwarty wymiar: wykluczenie świadomościowe. „Tak rozumiana ekskluzja przejawia się w pomijaniu lub tylko w sporadycznym dostrzeganiu, w obszarze społecznej komunikacji istnienia niektórych społecznych zbiorowości oraz utrwalania ich stereotypowego (często negatywnego, ale zawsze uproszczonego) wizerunku"32.

28 M. Jarosz, Wstęp. Obszary wykluczenia w Polsce, w: Wykluczeni. Wymiar społeczny, materialny i etniczny, red. M. Jarosz, Warszawa 2008, s. 10.

${ }_{29}$ M. W. Kozak, Wykluczenie - rozwój-przestrzeń, w: Wykluczeni. Wymiar społeczny..., dz. cyt., s. 211.

${ }_{30}$ J. H. Goldthorpe, O socjologii. Integracja badan i teorii, Warszawa 2012, s. 153.

31 A. Giddens, Socjologia, Warszawa 2005, s. 346-348.

32 B. Szatur-Jaworska, Ubóstwo i wykluczenie społeczne seniorów, w: Ubóstwo i wykluczenie społeczne. Perspektywa poznawcza, red. R. Szarfenberg, C. Żołędowski, M. Theiss, Warszawa 2010, s. 236. 
We współczesnej socjologii problemów społecznych wyraźnie widoczny jest rys studiów nad stosunkiem dominacji i marginalizacji oraz dążeniami do inkluzji ludzi dotkniętych tymi stosunkami ${ }^{33}$. Wyraźne jest także podejście terapeutyczne w uprawianiu tej dyscypliny naukowej: socjologia daje zaplecze teoretyczne, które może stanowić bazę do wypracowania rozwiązań praktycznego rozwikłania problemów społecznych poprzez pracę socjalną ${ }^{34}$.

Ryzyko wykluczenia oraz marginalizacja społeczna obecnie są przedmiotem badań nie tylko socjologii, lecz także innych nauk oraz retoryki organizacji międzynarodowych. Wedle analiz zjawiska social exclusion obejmujące jednostki, grupy społeczne i całe kraje, stanowią podstawową barierę integracji społecznej. Natomiast wyjście terminologii poza język nauki, interpretowane jest przez znawców jako zainteresowanie, a nawet przejaw publicznej troski i postrzeganie marginalizacji jako jednego z ważniejszych zagrożeń porządku społecznego i jakości życia otwartego społeczeństwa rynkowego ${ }^{35}$.

\section{Metodologia badań opinii kobiet uzależnionych od pracy}

Uzależnienie od pracy znajduje swoje odzwierciedlenie we wszystkich płaszczyznach życia jednostki. Do najistotniejszych następstw zalicza się: chroniczne zmęczenie, stany depresyjne, nastroje dysforyczne (gniewliwość, drażliwość, agresywność), zaburzenia poznawcze (trudności koncentracyjne, zaburzenia pamięci, zaburzenia procesów myślowych), trudności z umiejscawianiem zdarzeń w czasie, zaburzenia snu, zaburzenia emocjonalne, nadmierne zdenerwowanie, zniecierpliwienie, nieumiejętność zrelaksowania, zwiększone ryzyko uzależnienia od substancji psychoaktywnych. Pracoholizm wiąże się także z pogorszeniem stanu zdrowia somatycznego: alergie, bóle głowy, choroba niedokrwienna serca, niestrawność, choroba wrzodowa żołądka. Badacze zaobserwowali silne powiązanie ucieczki w pracę z zachowaniami społecznymi i zaburzeniami relacji: spadek efektywności, obniżenie kreatywności, nieumiejętność współpracy i konfliktowość, niezdolnossć do delegowania zadan,

\footnotetext{
33 K. Frysztacki, Socjologia problemów społecznych, Warszawa 2009, s. 265-266.

34 L. Miś, Problemy społeczne. Teoria, metodologia, badania, Kraków 2007, s. 117.

35 K. W. Frieske, Marginalność społeczna, w: Encyklopedia socjologii, t. 2, Warszawa 1999, s. 170-171; por. A. Power, W. J. Wilson, Social Exclusion and the Future of Cities, Centre for Analysis of Social Exclusion, London 2000; A. Rodriguez, E. Swyngedouw, F. Moulaert, Urban Restructuring, Social-Political Polarization, and New Urban Policies, w: The Globalized City. Economic Restructuring and Social Polarization in European Cities, eds. F. Moulaert, A. Rodriguez, E. Swyngedouw, Oxford 2003, s. 29-46.
} 
trudności komunikacyjne, wyznaczanie nierealnych celów, przedkładanie autokreatywności nad realizację celów realizowanych zespołowo, obniżenie zdolności do podejmowania ryzyka. Z punktu widzenia społecznego najważniejsze konsekwencje pracoholizmu to: zaniedbywanie relacji rodzinnych i przyjacielskich, redukcja kontaktów towarzyskich do relacji na poziomie znajomych z pracy, narastająca alienacja i jej doświadczanie, trudności w podtrzymywaniu współpracy zespołowej, przenoszenie zawyżonych standardów aktywności na rodzinę, szczególnie na dziecko ${ }^{36}$.

Konsekwencje te, szczególnie społeczne oraz świadomościowe, prowadzą uzależnionych do autowykluczenia społecznego. Terapia pracoholików zakłada wprowadzenie "planu równowagi” pomiędzy pracą a życiem osobistym i społecznym ${ }^{37}$. Zakłada także pracę nad emocjami, wyprowadzenie z samoizolacji, wyjście z zaprojektowanego przez osobę uzależnioną świata w kierunku realności i realnych relacji rodzinnych oraz społecznych ${ }^{38}$.

Wobec tak sytuowanego problemu uzależnienia od pracy, Bożena Wykusz, pod kierunkiem i opieką naukową Dariusza Tułowieckiego, przeprowadziła badania kobiet wykazujących znamiona ucieczki w pracę. Zakres badań ograniczono do kobiet, a próbę badawczą dobrano metodą kuli śniegowej (snowball sampling). Pierwsza badana kobieta była zaproszona do badań przez Bożenę Wykusz na drodze znajomości i pracy we wspólnej korporacji, natomiast kolejne respondentki zostały rekrutowane na zasadzie polecenia, znajomości i wskazania. Dobór próby ogniskował się wedle linii pracy w korporacji oraz korzystania z pomocy terapeutycznej. Ostatecznie trudno wykluczyć wadę tej metody doboru próby, to znaczy założyć, że przełamano rekrutację respondentek sobie wzajemnie znanych, o zbliżonych do siebie cechach. Założono, że celowy dobór próby metodą kuli śniegowej obejmie minimum 10 osób. W badanej próbie znajdą się kobiety, które utożsamiają się z nadmiernym zaangażowaniem w pracę, wykazują znamiona kompulsywności i ucieczki, zastanawiają się nad lub korzystają (korzystały) z terapii.

Celem badań było poznanie sytuacji osobistej i społecznej kobiet wykazujących znamiona ucieczki w pracę. Problem badawczy rysowały pytania: Czy pracoholizm jest szkodliwym skutkiem nadmiernego zaangażowania się w pracę? Kto jest pracoholikiem? W jakich okolicznościach życiowych zrodziły się kompulsywne ucieczki w pracę? Jakie są przyczyny pracoholizmu? Czy i w jaki sposób

36 M. Szpitalak, Przywiązani... do pracy. Zaangażowanie w prace jako odzwierciedlenie stylu przywiazania, „Psychologia Rozwojowa” 2010, nr 2, s. 19-20.

37 B. T. Woronowicz, Pracoholizm, http://psychiatria.mp.pl/uzaleznienia/72913,pracoholizm (10.12.2016).

38 D. Malinowska, Formy pomocy pracoholikom inne niż terapia, http://www.swiat-problemow.pl/formy-pomocy-pracoholikom-inne-niz-terapia/ (10.12.2016). 
pracoholizm zagraża relacjom społecznym? Czy pracoholizm sprzyja rozwojowi wiedzy, umiejętności? Czy pracoholizm wyklucza radość z pracy? Jakie typy pracoholików można wyróżnić wśród badanych? Jakie formy wsparcia socjalnego można kierować do osób uzależnionych od pracy, które uświadomiły sobie problem i podjęły terapię?

Zebranie materiału empirycznego nastąpiło od maja do września 2015 roku. Badania miały charakter pogłębionego wywiadu indywidualnego, w którym wyznaczono bloki pytań skupione wokół wskazanych powyżej pytań badawczych. W trakcie wywiadów wypowiedzi były zapisywane cyfrowo i archiwizowane. Rozmowa z respondentkami miała różnorodny przebieg: od jednego, kilkugodzinnego spotkania, po cykl 2-4 krótszych wywiadów skupionych na poszczególnych aspektach przyczyn, przebiegu, historii ucieczki od życia w pracę i uzależnienia oraz potrzebach zmiany bieżącej sytuacji życiowej. W badaniu na etapie przygotowań i spotkania uczestniczyło zaplanowanych dziesięć kobiet zamieszkujących Kraków i Małopolskę, które zadeklarowały chęć udziału oraz zgodziły się wstępnie na publikację wyników badań. Posiadały one wykształcenie wyższe, ugruntowaną pozycję zawodową, dobrą lub bardzo dobrą sytuacje ekonomiczną, doświadczenie zawodowe. Jednak w trakcie wywiadów trzy z nich zrezygnowały i przerwały czynności badawcze. Kobiety te nie wyraziły także zgodny na wykorzystanie już zgromadzonego materiału empirycznego (w postaci nagrania).

Wywiady zostały przeprowadzone w następujących miejscach: $\mathrm{w}$ domu respondentki, w kawiarnia w centrum Krakowa, w przedziale biznesowym pociągu relacja Kraków - Warszawa, w domu prywatnym prowadzącej badania k. Krakowa. Ostatecznie wywiady przeprowadzono $\mathrm{z}$ siedmioma kobietami w wieku 30-39 lat. Autoryzowano je w październiku 2015 roku. Jednak w trakcie autoryzacji dwie z kobiet zrezygnowały z możliwości dalszego wykorzystania zebranego materiału empirycznego, tłumacząc, że zebrany materiał nie odzwierciedla ich obecnych poglądów. Opinie te - ich zdaniem - uległy radykalnej zmianie, ponieważ zaszły w ciąże i ich spojrzenie na samą siebie, świat, także na pracę i rodzinę, uległy fundamentalnym przeobrażeniom.

Niniejsza analiza uzyskanego materiału empirycznego jest ponowną próbą analizy zebranego materiału empirycznego, odmienną niż w swoim czasie wykazała $w$ raporcie $z$ badań Bożena Wykurz. Niniejszy tekst jest nowym raportem $\mathrm{z}$ badań sporządzonym $\mathrm{w}$ kontekście konieczności wsparcia socjalnego osób uciekających w pracę. Pracoholizm - jak każde uzależnienie - rodzi alienację i samowykluczenie społeczne. Dlatego na bazie zebranego materiału empirycznego podjęto się próby ukazania dialogu jako czynnika przełamującego alienację i automarginalizację społeczną uzależnionych kobiet. 
Dla potrzeb raportu przyjęto hipotezy badawcze: 1 . Autowykluczenie społeczne rodzi ból osób uzależnionych i ma postać izolacji społecznej. 2. Wykluczenie społeczne wymaga przełamania poprzez dialog - reaktywację relacji społecznych.

\section{Autowykluczenie kobiet uciekajacych w pracę}

Sytuacja ucieczki w pracę wśród badanych kobiet nie była wyborem nagłym, lecz przygotowywanym przez dom rodzinny i typ osobowości. Jedna z respondentek przyznała: „Moi rodzice z wykształcenia są nauczycielami języka polskiego. Tato specjalność starsze klasy - obecnie gimnazjum. Mamę bardziej ciągnęło do młodszych pociech. Zresztą edukację mają wbudowaną w życie, w myślenie, w działanie, w każdy krok... Idealne małżeństwo - połączenie Siłaczki i Judyma..." (Anna, lat 39). Wraz z jej urodzeniem rodzice zaczęli realizację własnego scenariusza na jej życie, bez uwzględniania jej planów i emocji: „Kiedy pojawiłam się na świecie, otrzymałam imię Anna, przecież Leśmian to ulubieniec taty. Zresztą każde $\mathrm{z}$ nas, ma imiona $\mathrm{z}$ drugim JA. To był pierwszy objaw mojego piętna, mojego totalnego zniewolenia. Od imienia wszystko się zaczęło. Tak naprawdę, rodzice ustalili mi całe życie. I jak widać, zrobili to na tyle dobrze i konsekwentnie, że będąc dzisiaj tu, gdzie jestem, spełniłam ich oczekiwania... [...] Kiedy należało wybrać szkołę średnią, jasnym było, że muszę obrać kierunek humanistyczny. Przecież tradycja musi być kontynuowana. Było mi z tym źle. Nie chciałam wiązać swojego życia z edukacją innych... Próbowałam, ale widziałam, że nie ma to sensu. Zresztą, postanowiłam wytrzymać w szkole i „zbuntować” się, idąc na studia” (Anna, 39).

Styl wychowania zrodził nieśmiałość i wycofanie. Został on wzmocniony brakiem integracji z grupą rówieśniczą: „... byłam bardzo nieśmiała i to mnie blokowało... Pytasz, co pamiętam [z liceum] - spokojnie mogę powiedzieć, że wstyd, smutek, żal. [...] Rodzice uważali, że w człowieku liczy się tylko intelekt, empatia i wartości, które dla dorastającej młodzieży niekiedy były bardzo obce. Ja nie miałam nowych, ładnych ubrań. Nie używałam makijażu. Nosiłam długie włosy, zawsze splecione w słowiański warkocz. Patrząc na mnie, widziałaś, biedną wiejską dziewczynę, która zgubiła się w wielkim mieście” (Anna, 39).

Już w młodości jedna z kobiet żyła w totalnej alienacji, która w dorosłym życiu przyjmie postać braku autentycznych relacji: „... byłam totalnym odludkiem. Siedziałam sama w pierwszej ławce. Nie miałam nigdy koleżanek, z którymi mogłam się dzielić młodzieńczymi przeżyciami i problemami. Kiedy moi rówieśnicy spędzali czas na imprezach, wieczornych spotkaniach na mieście, ja grzecznie wracałam do domu, odrabiałam lekcje i obowiązkowo czytałam ogromne ilości książek. Przez cały okres szkoły średniej nie miałam «chłopaka», nie wiedziałam co to «motylki w brzuchu» i szaleństwo hormonów. Bałam 
się ludzi. Byłam bardzo nieśmiała. Trudno wchodziłam w nowe relacje. Miałam w sobie jakąś wewnętrzną blokadę, która chyba nigdy nie została przełamana" (Anna, 39). Samotność była skutkiem wycofania sie z życia wymuszonego stylem wychowania: „Tak naprawdę rodzice ustalili mi całe życie. [...] Przecież mi nic nie wolno! Każde wolne chwile od nauki spędzałam z tatą w górach. Góry, to było ukochane miejsce taty" (Anna, 39).

Brak relacji $z$ innymi miał fundament $w$ braku relacji ze sobą i własnym życiem. Jedna $\mathrm{z}$ respondentek bardzo wyraźnie nie zgadzała sie nigdy z własnym losem, ale nie miała odwagi, by przejąć nad nim kontrolę: „Tak naprawdę, rodzice ustalili mi całe życie. [...] Przecież, mi nic nie wolno! Każde wolne chwile od nauki, spędzałam $\mathrm{z}$ tatą $\mathrm{w}$ górach. Góry, to było ukochane miejsce taty. [...] Po otrzymaniu dyplomu, zostałam zatrudniona przez mamę, w szkole, którą sama kończyłam. Życie zrobiło sobie mega duże kółko. Wróciłam tam, gdzie nigdy nie chciałam się znaleźć" (Anna, 39).

Wycofanie istnieje u jednej kobiet na podłożu poczucia wyższości, swoistego „bycia bogiem”. To „bóstwo” - autokreacja losów, brak zależności od innych, całkowita niezależność i absolutna wolność imponują, stają się celem, określają osobowość: „Po trzech latach w pracy, poznałam na jednej z działowych imprez kolegę z innego działu. [...] Widziałam, jak inni na niego patrzą - jak na boga, stwórcę, wizjonera. Nawet nie wiesz, jak bardzo mnie to fascynowało. Chyba w głębi duszy, chciałam być taka jak on... Niczym jak Stwórca - planował stworzenie, dzieło niepowtarzalne, nieskazitelne. Tak idealne, że zawsze był skazany na sukces" (Wiktoria, 32). To pragnienie byciem bogiem - kreatorem niezależnym od rzeczywistości daje poczucie absolutnej niezależności od innych i problemów świata: „Wierzę, że wybrałam dobrze i tego się trzymam, licząc, że niespodzianki losu nie będą mnie dotyczyć" (Karolina, 32).

Pielęgnowanie w sobie poczucia bycia bogiem ma swą bazę w poczuciu perfekcjonizmu: „Więcej rozmawiam, niż żądam. Nie analizuję ludzkich błędów...” (Wiktoria, 32). „Lubię wzbudzać zachwyt, swoim wykształceniem, wiedzą, umiejętnościami. To jest takie ekscytujące" (Karolina, 36). Perfekcjonizm rodzi poczucie bardzo skrupulatnej kontroli siebie i otoczenia, charakterystycznej dla wszelkich uzależnień: „W każdym momencie decyduję o tym, co się wydarzy w moim życiu. Gdzie skieruję swoi kroki. To jest komfort, bycia niezależnym" (Karolina, 32). Pyt.: „Czy zakładasz, że coś takiego może pojawić się w Twoim życiu?”. Odp.: „Nie mówię, że nie. Ale robię wszystko, aby temu zapobiec. Robię badania kontrolne, zdrowo się odżywiam, używam antykoncepcji, mam stałego partnera. To dużo. [...] jestem zimna i wyrachowana" (Karolina, 32).

Tak wykreowane bóstwo domaga się swoistej adoracji: „Lubię wzbudzać zachwyt, swoim wykształceniem, wiedzą, umiejętnościami. To jest takie ekscytujące"(Karolina, 36). Uwielbienie jest postrzegane jako uzasadnione ze wglądu na CV naznaczone sukcesem i wybitny wysiłek włożony w kształt kariery 
zawodowej: „Studnia wybrałam w Irlandii - Zarządzanie. Następnie obrałam kierunek USA i zostałam absolwentem Harvard Business School. [...] Wiesz, co to oznacza dla kobiety ukończyć taki kierunek? Prestiż, władza, dominacja, szacunek" (Karolina, 36).

W ogólnym spojrzeniu na życie, jako cel wskazywany jest sukces: „... w kapitalizmie pieniądz daje prawo do posiadania praw... Z czasem to posiadanie prawa staje się twoim powietrzem, heroiną. Nie możesz bez niego funkcjonować" (Wiktoria, 32). Sukces jest miarą godności osoby: „A odstawienie, detoks niszczy cię, znikasz ze świata, stajesz się bezimiennym, bezwartościowym przedmiotem" (Wiktoria, 32).

Sukces ten obejmuje przede wszystkim wymiar ekonomiczny, ale także utożsamiane z nim życie bez porażek, niezależność, swobodę, życie dla siebie: „[...] dać sobie swobodę” (Wiktoria 32). „[... ] ja już taka jestem. Stworzono mnie z innej gliny. Mój plan stworzenia zakłada życie, które nie przewiduje odpowiedzialności za drugą osobę” (Karolina, 32). „Nie muszę się martwić o milion spraw i problemów, które mają moje siostry [które mają dzieci]" (Karolina, 32). Pyt.: „To jest komfort braku odpowiedzialności?”. Odp.: „Dokładnie tak” (Karolina, 32). Pyt.: „Wiesz, że to bardzo hedonistyczne podejście do życia”. Odp.: „Wiem i jest mi z tym dobrze. Nie mam zamiaru tego zmieniać. Mam wszystko, czego potrzebuję do życia, na takim poziomie, jaki chcę, aby był. Jeśli mam ochotę spędzić tydzień w Paryżu, bo właśnie jest Fashionweek, to bukuję bilet, zabieram laptopa, wsiadam w samolot i życie nabiera nowych barw" (Karolina 36).

Jednak życie w tak skonstruowanym dobrostanie ma swoją cenę - brak głębokich relacji: „Nie byłam lubiana, ale wynika to $z$ faktu rywalizacji. [...] moje doświadczenia były podawane za wzór do naśladowania" (Marzena, 30). Nie zawsze ten stan jest dotkliwy. Czasem wystarczą relacje pozorne lub wielkość pobieżnych znajomości ograniczających się do pracy lub zabawy: „Nie jestem sama, mam milion przyjaciół na całym świecie. Pokaż mi drugą taką osobę, która rano romansuje w Tokio, a wieczorem we Włoszech? To jest mój wybór i nie ma zamiaru się nikomu z niego tłumaczyć" (Karolina, 32). Inna z badanych osób wybrała relację pozorną, chwilową, zamiast silnego i głęboko emocjonalnego związku, który wymaga zaangażowania oraz wysiłku. Pyt.: „Czy Paweł również odwzajemniał Twoje uczucia?”. Odp.: „W pewnym sensie tak. [...] Chyba nie chciałam być sama. [...] W sumie to nawet nie było czasu, aby spokojnie porozmawiać lub w milczeniu patrzeć na siebie. Chyba tego mi bardzo brakowało. [...] ...chciałam założyć rodzinę, więc założyłam, że romans z Pawłem to tylko chwila i będzie jeszcze czas na poważne życie. [...] Zaszłam w ciąże i poddałam się aborcji. [...] Powiedział, tylko tyle: «chyba to oczywiste, że go nie urodzisz» (Wiktoria, 32). 
Ucieczka w pracę u badanych kobiet dokonuje się na podłożu silnych lęków. Są to lęki przed relacjami damsko-męskimi: „Nie ukrywam, że cieszyłam się dość dużym zainteresowaniem mężczyzn, ale zawsze w sytuacji podbramkowej, chowałam głowę w piasek. [...] Tak naprawdę, zawsze kończyło się na pierwszym spotkaniu, a jeśli czułam, że znajomość może posunąć się dalej, robiłam wszystko, aby tego uniknąć. Czasami mówiłam wprost, że nie jestem zainteresowana lub nie odbierałam telefonów, nie reagowałam na zaczepki. Potencjalny partner odchodził w niepamięć" (Marzena, 30); ucieczka przed przeszłością: „Miałam na niej więcej niż trzy upadki. A każdy z nich degradował mnie jako człowieka" (Anna, 39); ucieczka przed zachowaniem ocenionym jako ważny błąd życiowy: „Zrobiłam coś, co było sprzeczne z moją naturą. Dzisiaj nie cofnę czasu, nie zmienię, podjętych decyzji. Nie chcę, też na siłę, zmieniać świat, tylko po to, aby odkupić swoje winy" (Weronika, 32).

Zachowania kompulsywne zaczynały się bardzo „niewinnie”, nie wskazując na możliwość autowykluczania się z życia. Kobiety doświadczały wręcz przeciwnych emocji - powodzenia, sukcesu, zwycięstwa: „Po studiach długo nie mogłam dostać pracy, więc kiedy nadarzyła się okazja w dużej firmie, zgodziłam się na ich ofertę. Pomyślałam wtedy, co mi szkodzi, zacznę na siebie zarabiać, stanę się niezależna od rodziców. Będę mogła odłożyć zarobione pieniądze i spełniać swoje marzenia... [...] Jak widać przeciągam tak już dziesięć lat.... I nawet nie wiem, w którym momencie praca zabrała mi marzenia" (Wiktoria, 32). „Dzisiaj mam 39 lat i jestem sama. Nie mam męża, kochanka, dzieci. Nie mam nikogo. Zostaje mi tylko praca, którą chyba już nawet polubiłam” (Anna, 39). „Ale nigdy nie sądziłam, że tak mi się ułoży życie. Chyba trochę się zapędziłam, zapomniałam w tym wszystkim. Zarówno praca, pieniądze, jak i znajomość z Pawłem, wywróciła moje życie do góry nogami. Czegoś chyba zabrakło w pewnym momencie. Nie wiem, może miłości, akceptacji rodziców. A może powinnam wcześniej odejść z pracy i wrócić do tego, o czym marzyłam na studiach. Teraz to i tak już niczego nie zmieni. Przeszłość zmieniła teraźniejszość i muszę ją zaakceptować. Wtedy mogę normalnie funkcjonować. Praca jest alternatywą i takiego dokonałam wyboru. Jest dobrze. Muszę w to wierzyć" (Weronika, 32).

Dwie z kobiet nie wykazują świadomości autowykluczenia, wręcz przeciwnie, ich sytuacja jest wyborem, absolutnym dobrostanem, stylem życia, którego nie chcą zmieniać: „Wiem, że wydaje się to dziwne, że nie chcę założyć rodziny, urodzić dziecka, że wybieram mimo wszystko pracę i tylko pracę. Ale tak czuję, całą sobą, i nie chcę robić niczego wbrew swoim przekonaniom” (Karolina, 32). Pyt.: „Czy próbowałaś coś zmienić, bardziej otworzyć się na ludzi?”. Odp.: „Ale po co?” (Marzena, 30). 


\section{Potrzeba dialogu - czyli wyjście z izolacji}

W wypowiedziach badanych kobiet, obok zadowolenia ze stylu życia i odniesionego sukcesu ekonomiczno-zawodowego, istnieje silne pragnienie relacji. Lęk przez samotnością obejmuje brak relacji z rówieśnikami w okresie studiów i pierwszych lat pracy: „Każde wolne chwile od nauki, spędzałam z tatą w górach. [...] A wiesz, co to oznacza dla młodej kobiety? [...] To oznacza samotność!” (Anna, 39); brak rodziny, szczególnie dzieci: „...już nigdy nie urodzę dziecka. Nie dam nikomu życia, nie zbuduję rodziny. Nie zaśpiewam do kołyski, nie zbuduję domku z piasku, nie namaluję laurki, nie, nie, nie, nie - już nic NIE” (Weronika, 32); codzienną samotność: „Trzeba być samemu, zawsze samemu, aż stąd do wieczności" (Weronika, 32).

Jedna z kobiet, dotychczas poddana oddziaływaniu rodziców i niemająca odwagi przeciwstawić sie ich planom co do siebie, nie czuła w sobie siły, by jasno przeciwstawić się im, gdy w jej życiu pojawiła się relacja. „Na początku nie byli z tego [relacji z mężczyzną] zadowoleni” (Anna, 39). Przyjęła jednak bierną strategię postawienia ich w sytuacji dokonanej: „Ale później bardzo mocno wspierała mnie mama. Chyba dotarło do niej, że potrzebuję tego. Że zaczynam już dziwaczeć, i jeśli coś nie ulegnie zmianie w moim życiu, to może już być za późno dla mnie, abym wróciła do «normalności»" (Anna, 39).

Relacja z mężczyzną, w którą weszła na pewnym etapie życia jedna z kobiet, stanowiła swoiste światło dla całego jej życia. Relacja wyrwała ją z niewiary w siebie, $\mathrm{z}$ alienacji, $\mathrm{z}$ bezsensu, $\mathrm{z}$ ucieczki w pracę: „Tam poznałam wspaniałego mężczyznę. Chyba się zakochałam. Początkowo nie wiedziałam o tym, bo przecież to uczucie było mi bardzo obce. Dopiero z czasem zrozumiałam, jak wspaniale się z tym czuję. [...] Zmienił wszystko. Chciało mi się żyć, tańczyć, śpiewać. Akceptował mnie taką, jaką byłam. Nie musiałam się już wstydzić. Byłam szczęśliwa. Spotykaliśmy się dość często. Czasami nawet kilka razy w miesiącu. Albo ja jechałam do niego, albo on przyjeżdżał do mnie. [...] Wiesz, byłam w tej dobrej sytuacji, że dostałabym wtedy mieszkanie. Szkoła miała bardzo dobry dom nauczyciela, blisko szkoły. Było to dla mnie zbawienie. W końcu, po tylu latach los się do mnie uśmiechnął. I nawet przez chwilę byłam wdzięczna rodzicom, że zostałam nauczycielem. Dzięki temu miałam własny kąt i miłość życia" (Anna, 39).

Jednak po kilku miesiącach szczęścia relacja ta została przerwana przez śmierć osoby kochanej: „Jechał do mnie - rozumiesz do mnie, do swojej miłości. Nie mogę się z tym pogodzić. To jest takie okrutne, niesprawiedliwe. Tak nie można robić. W nocy z niedzieli na poniedziałek, na pustej drodze, w biały dzień, uderzył w niego samochód ciężarowy. Zginął na miejscu. Nie zdążyłam się z nim pożegnać, przytulić, porozmawiać. To wszystko jest bez sensu. 
Nawet nie wiem, jak dojechałam na pogrzeb" (Anna, 39). W sytuacji utraty relacji z mężczyzną, uaktywniła się relacja z jednym z rodziców. Ta relacja z kolei była silnym wsparciem w traumie śmierci: „Pamiętam, że mama była przy mnie. Chyba pierwszy raz była dla mnie matką" (Anna, 39).

Utrata relacji pozwoliła zrozumieć, jak głęboka i emocjonalna relacja może wyrwać z alienacji: „...śmierć. Okrutna, bezduszna, czarna moc, zabrała mi wszystko. Wszystko to, co stworzyło mnie nową. Niczym feniks, powstałam z popiołu. Andriej był moim światłem, powietrzem, oczami, sercem, duszą. Dzisiaj jestem tylko Anną. Jedną z miliona szarych Ann na świecie. Wielkie imię, które miało być nadzieją i radością, przerodziło się w porażkę" (Anna, 39). Inna $z$ kobiet nadal żyje w nadziei, że wejdzie w relację, która odmieni jej życie: „...może kiedyś przyjdzie taki czas, że słońce skieruje na mnie swe promienie" (Marzena, 30).

\section{Wnioski}

Zebrany materiał empiryczny pozwala na wniosek, że praca - jako główny regulator życia - prowadzi do izolacji i samowykluczenia z życia społecznego. Praca może być zarówno czynnikiem wykluczającym (ucieczka od rzeczywistości w pracę), jak i stanowić przyczynę alienacji (nadmierna praca powoduje alienację społeczną). Lęki mogą zarówno być podstawą zachowań kompulsywnych, jak przeciwnie, mogą być skutkiem izolacji i pracoholizmu. W ten sposób osoby kompulsywnie uciekające w pracę wchodzą w zamknięty krąg ograniczającego je koła. Nadmierne uwikłanie w pracę może rozwijać kompetencje zawodowe i prowadzić do sukcesów zawodowych i ekonomicznych, ale jednocześnie zagraża relacjom rodzinnym i społecznym. Terapia pracoholików - „plan równowagi” - to przerwanie koła lęku i ucieczki, która winna być wspomagana przywracaniem do relacji rodzinnych i antycypacją w pozazawodowym życiu społecznym. Może dokonywać się ona poprzez dialog - odkrycie w innych partnerów dialogu, z którymi wspólnie poszukuje się prawdy o sobie, o świecie, o życiu. Inni nie są więc wrogami, agresorami, zagrożeniem, lecz twórczym środowiskiem interakcji.

Postawione u progu analiz hipotezy można zweryfikować pozytywnie: 1. Autowykluczenie społeczne rodzi ból osób uzależnionych i ma postać izolacji społecznej. 2. Wykluczenie społeczne wymaga przełamania poprzez dialog - reaktywację relacji społecznych budowanych w celu wspólnego odkrywania i budowania rzeczywistości.

Terapia psychologiczna pracoholików winna być wspomagana terapią społeczną: pracą z jednostką, z rodziną, w społecznościach. Wnioski takie można 
wyciągnąć nie tylko na podstawie zaprezentowanego materiału empirycznego. Także odmowa wykorzystania w analizach wywiadów wcześniej przeprowadzonych z kobietami wykazującymi symptomy uzależnienia, świadczy o leczniczym wymiarze relacji: zajście w ciążę powoduje zmianę życia, wyjście z kompulsywności pracy i konieczność budowania relacji. Rodzina bowiem jest „podstawowym otoczeniem społecznym" ${ }^{39}$, w dialogu z którym osoba uzależniona może powrócić do życiowej równowagi i aktywnego udziału w życiu społecznym.

\section{Bibliografia}

Ahmed I., Khan M. K., Predicting Work Motivation Through Job Satisfaction and Turnover Intentions: The Explanatory Role of Heavy Work Investment, „The Lahore Journal of Business" 4 (2015), nr 1, s. 75-89.

Beek I., van, Hu Q., Schaufeli W. B., Taris T. W., Schreurs B., For fun, love, or money: What drives workaholic, engaged, and burned-out employees at work?, „Applied Psychology. An International Review" 61 (2012), no. 1, s. 30-55.

Beek, I, van, Taris T. W., Schaufeli W. B., Brenninkmeijer V., Heavy work investment: its motivational make-up and outcomes, „Journal of Managerial Psychology” 29 (2014), no. 1, s. 46-62.

Dudek B., Pracoholizm - szkodliwy skutek nadmiernego zaangażowania sie w pracę, „Medycyna pracy" 2008, nr 3 (59), s. 247-254.

Frieske K. W., Marginalność społeczna, w: Encyklopedia socjologii, t. 2, red. W. Kwaśniewicz, Warszawa 1999, s. 167-171.

Frysztacki K., Socjologia problemów społecznych, Warszawa 2009.

Giddens A., Socjologia, Warszawa 2005.

Goldthorpe J. H., O socjologii. Integracja badan i teorii, Warszawa 2012.

Golińska L., Pracoholizm - istota, konsekwencje i uwarunkowania, „Folia Psychologica” 2010, nr 14, s. 97-107.

Golińska L., Pracoholizm - uzależnienie czy pasja, Warszawa 2008.

Golińska L., Pracoholizm inaczej, Warszawa 2014.

Guerreschi C., Nowe uzależnienia, Kraków 2005.

Hornowska E., Paluchowski W. J., Praca - skrywana obsesja. Wyniki badań nad zjawiskiem pracoholizmu, Poznań 2007.

Jarosz M., Wstęp. Obszary wykluczenia w Polsce, w: Wykluczeni. Wymiar społeczny,

39 D. Tułowiecki, Polityka społeczna a pedagogika rodziny, w: Pedagogika rodziny. Podejście systemowe, t. 1: Familiologia, red. M. Marczewski, R. Gawrych, D. Opozda, T. Sakowicz, A. Solak, Gdańsk 2016, s. 101. 
materialny i etniczny, red. M. Jarosz, Warszawa 2008, s. 7-16.

Judzińska A., Niekonwencjonalna walka ze stresem - konteksty i kulturowe uwarunkowania, „Studia Edukacyjne” 2015, nr 35, s. 131-147.

Kozak M. W., Wykluczenie - rozwój - przestrzeń, w: Wykluczeni. Wymiar społeczny, materialny i etniczny, red. M. Jarosz, Warszawa 2008, s. 211-242.

Łuczak E., Pracoholizm - droga do sukcesu czy zniewolenia, w: Nowe oblicza uzależnień, red. E. Łuczak, Olsztyn 2009, s. 151-160.

Malinowska D., Pracoholizm. Zjawisko wielowymiarowe, Kraków 2014, s. 15.

Miś L., Problemy społeczne. Teoria, metodologia, badania, Kraków 2007.

Oates W., Confessions of a workaholic: The facts about work addiction, New York 1971.

Power A., Wilson W. J., Social Exclusion and the Future of Cities, Centre for Analysis of Social Exclusion, London 2000.

Rodriguez A., Swyngedouw E., Moulaert F., Urban Restructuring, Social-Political Polarization, and New Urban Policies, w: The Globalized City. Economic Restructuring and Social Polarization in European Cities, eds. F. Moulaert, A. Rodriguez, E. Swyngedouw, Oxford 2003, s. 29-46.

Snir R., Harpaz I., Beyond workaholism: Towards a general model of heavy work investment, „Human Resource Management Review” 22 (2012), s. 232-243.

Szatur-Jaworska B., Ubóstwo i wykluczenie społeczne seniorów, w: Ubóstwo i wykluczenie społeczne. Perspektywa poznawcza, red. R. Szarfenberg, C. Żołędowski, M. Theiss, Warszawa 2010, s. 234-255.

Szpitalak M., Przywiązani... do pracy. Zaangażowanie w prace jako odzwierciedlenie stylu przywiąania, „Psychologia Rozwojowa” 15 (2010), nr 2, s. 19-30.

Schaufeli W. B., Shimazu A., Taris T. W., Being driven to work excessively hard: the evaluation of a two-factor measure of workaholism in the Netherlands and Japan, Cross-Cultural Research" 43 (2009), s. 320-348.

Schaufeli W. B., Taris T. W., Van Rhenen W., Workaholism, burnout, and engagement: three of a kind or three different kinds of employee well-being?, „Applied Psychology: An International Review", 57 (2008), no. 4, s. 173-203.

Tułowiecki D., Aktywność seniorów jako sposób na przełamanie wykluczenia społecznego w opisach prasy regionalnej, „Studia nad Rodziną” 17 (2013), nr 2 (33), s. 379-407.

Tułowiecki D., Polityka społeczna a pedagogika rodziny, w: Pedagogika rodziny. Podejście systemowe, t. 1: Familiologia, red. M. Marczewski, R. Gawrych, D. Opozda, T. Sakowicz, A. Solak, Gdańsk 2016, s. 90-104.

Wachowiak J., Dysfunkcyjne zachowania pracowników, Warszawa 2011.

Wojdyło K., Pracoholizm - istota konstruktu i trafność nomenklatury jako aktualne problemy $w$ badaniach nad zjawiskiem. Komentarz do Staszczyk i Tokarz (2015), „Roczniki Psychologiczne" 18 (2015), nr 4, s. 541-552.

Wojdyło K., Work craving - teoria uzależnienia od pracy, „Nauka” 2013, nr 3, s. 87-97. 
Giannini M., Scabia A., Workaholism: An Addiction or a Quality to be Appreciated?, „Journal of Addiction Research \& Therapy" 5 (2014), no. 3, https://www.omicsonline.org/open-access/workaholism-an-addiction-or-a-quality-to-be-appreciated-2155-6105-5-187. php?aid=30501 (19.04.2017).

Malinowska D., Formy pomocy pracoholikom inne niż terapia, http://www.swiat-problemow. pl/formy-pomocy-pracoholikom-inne-niz-terapia/ (10.12.2016).

Woronowicz B. T., Pracoholizm, http://psychiatria.mp.pl/uzaleznienia/72913,pracoholizm (10.12.2016). 


\section{Spis treści}

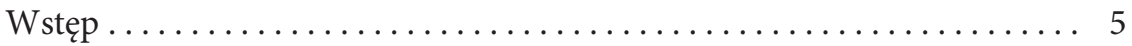

\section{Część 1. Człowiek w połrzebie z perspekływy filozofii}

Jarosław Kupczak OP

Personalistyczne podstawy troski o drugiego $\ldots \ldots \ldots \ldots \ldots \ldots \ldots . . \ldots$

Jan Mazur OSPPE

Rola i znaczenie dialogu w pracy socjalnej................ 27

Jadwiga Skrzypek-Faluszczak

Rola i znaczenie antycznej myśli etycznej w pracy socjalnej .......... 35

Grzegorz Krupa

Psychoterapia humanistyczno-egzystencjalna w świetle

filozofii spotkania .............................. 53

\section{Tadeusz Kamiński}

Praca socjalna i działalność charytatywna - wspólna droga do człowieka w potrzebie $\ldots \ldots \ldots \ldots \ldots \ldots \ldots \ldots \ldots \ldots \ldots \ldots \ldots \ldots$

Część II. Tożsamość służb socjalnych: aksjologia i mełody pomagania

\section{Monika Wiktorowicz-Sosnowska}

Kształtowanie tożsamości zawodowej studentów pracy socjalnej jako jeden z podstawowych elementów profesjonalnego pomagania $\ldots . \quad 87$ 


\section{Olga Maciejewska}

Znaczenie doświadczania wartości w edukacji studentów pracy socjalnej

\section{Marek Okłaba}

Towarzyszenie duchowe - metoda pracy socjalnej stosowana przez br. Jerzego Marszałkowicza

\section{Jolanta Sokołowska}

Relacyjny charakter pedagogik ulicy $\ldots \ldots \ldots \ldots \ldots \ldots \ldots \ldots \ldots$

\section{Beata Mańkowska}

Problem ochrony zdrowia psychicznego pracowników instytucji pomocy społecznej - z perspektywy superwizora . . . . . . . . . 147

\section{Część III. Dialog i solidarna wspólnota - wnioski z badań i analiz}

\section{Renata Suchanek}

Społeczeństwo w dialogu z żebrakami - idea i formy pomocy . . . . . . 167

\section{Piotr Fraczek, Patrycja Pater}

Determinanty dobroczynności na Podkarpaciu $\ldots \ldots \ldots \ldots \ldots \ldots .181$

\section{Wiesław Antosz}

W stronę spotkania dorosłości osób z niepełnosprawnością intelektualną

\section{Beata Szluz}

Spółdzielnia socjalna. Kreowanie podmiotu ekonomii społecznej . . . 221

\section{Dariusz Tułowiecki}

Dialog jako czynnik przełamywania ryzyka autowykluczenia społecznego pracoholików. Analiza opinii kobiet uciekających w pracę .......... 233 
4/ Uniwersytet Papiesk

Tê. Jana Pawła I 
4/ Uniwersytet Papiesk

Tê. Jana Pawła I 